\title{
Study on Academic Self Image of B.Ed., Trainees in Perambalur District
}

\section{OPEN ACCESS}

Manuscript ID:

EDU-2020-08032764

Volume: 8

Issue: 3

Month: June

Year: 2020

P-ISSN: $2320-2653$

E-ISSN: 2582-1334

Received: 14.04.2020

Accepted: 15.05.2020

Published: 01.06.2020

Citation:

Rajendran, P., and R. Anandarasu. "Study on Academic Self Image of B.Ed., Trainees in Perambalur District." Shanlax International Journal of Education, vol. 8 , no. 3, 2020, pp. 102-107.

DOI:

https://doi.org/10.34293/ education.v8i3.2764

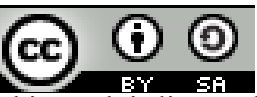

This work is licensed under a Creative Commons Attribution-ShareAlike 4.0 International License

\section{P. Rajendran}

Ph.D. Scholar, Department of Education, Tamil University, Thanjavur, Tamil Nadu, India https://orcid.org/0000-0002-6311-7383

\section{R. Anandarasu}

Assistant Professor, Department of Education, Tamil University, Thanjavur, Tamil Nadu, India

\section{Abstract}

The present study was Academic Self Image of B.Ed., trainees in the perambalur district. The main objectives of the study are to find out the academic self-image of B.Ed., trainees concerning the Demographic variables such as gender, year of study, subject, locality of college, marital status. A sample was using the survey method, and the simple random sampling technique was adopted for the selection of the sample. The samples of 941 B.Ed., trainees were taken from the study. The main findings of the study are there is no significant difference in the mean scores on the academic selfimage of B.Ed., trainees concerning their gender, subject, and marital status. There is a significant difference in the mean scores on the academic self-image of B.Ed., trainees concerning their year of study, locality of college. It's my conclusion that the present study reveals that there is more number of B.Ed., Trainees have a high academic self-image.

Keywords: Academic Self Image, B.Ed., trainees.

\section{Introduction}

Self Image is the individual's consciousness of his/her mental and physical characteristics. With a constructive self-image, we own our assets and potentials while being realistic about our liabilities and limitations. A negative self-image focuses on our faults and weaknesses, distorting failure, and imperfections. In this study, the various dimensions of self-image selected are personal, psychological, social, coping, educational, and moral self-images. A concept like a self-image, self-perception, etc. has become part of the body of conventional wisdom, and to some extent, at least these influence contemporary educational thinking. The academic achievement is expected to depend on the self-images of student teachers found in a classroom.

\section{Need and Significance of the Study}

Teaching is one of the noble professions in the world. The teachers are the pillars of society for they educate and mold the future citizens of a country. Teaching is a revered profession in India also. A safe and secure career, great economic reward, and regular annual vacations are enticing hordes of promise young men and women to join this teaching profession. Teaching requires, apart from the requisite education and degree, a flair for interacting with the students and the capability of explaining things in clear, lucid terms to the students. Rousing the students from their apathetic slumber and watching their interest grow in studies in the greatest reward for a teacher. For being a good teacher, he not only needs to be wise but also be patient and understanding. Teachers not only supplement a student's intellect but also contribute to the regular development of his or her personality. 
The influence of schooling in the narrow sense of the term or education in the broader sense may have a positive, negative, or natural effect on a studentteacher self-image. Whether planned or unplanned, the influence of the college or, more specifically, the teacher educators have a great deal to do with the developing self-image. Hence, there is a felt need to study, Study on Academic Self Image of B.Ed., trainees in perambalur district.

\section{Objectives of the Study}

The following objectives were framed for the present research study.

- To find out the level of the academic self-image of B.Ed., trainees.

- To find out the academic self-image of B.Ed., trainees concerning the Demographic variables such as gender, year of study, subject, locality of college, marital status.

\section{Hypotheses of the Study}

These Hypotheses of study are as follows given below.

1. The level of the academic self-image of B.Ed., trainees.

2. There is no significant difference in the mean scores on the academic self-image of B.Ed., trainees concerning the Demographic variables such as gender, year of study, subject, locality of college, marital status.

\section{Limitation of the Study}

The present study has certain limitations.

1. The study is limited to four B.Ed., Colleges in Perambalur District.

2. The correctness of information provided by the respondents in the personal Bio-Data could not be established.

3. The study is limited to $941 \mathrm{~B}$. Ed, trainees in Perambalur district.

\section{Method of Study}

The present study was adopted with the survey method and simple random sampling techniques.

\section{Sampling Technique and Sample Size}

A simple random sampling technique was adopted for the selection of the sample. The sample size is 941which includes 210 male and 731 female Student Teachers studying from 09 self-financed College of Education in the Perambalur district of Tamilnadu.

\section{Tool Used for the Study}

Academic Self -Image Scale was developed by the investigator with the help of supervising our Guide. The Reliability Co-efficient is 0.79 measured by the split-half method.

\section{Data Collection Procedure}

The investigator got prior permission from the principal of the college approached, the B.Ed., trainees of the college for getting necessary cooperation. I am explaining the purpose of the research title of the Academic Self-Image of the B.Ed., Trainees. I am provided with the tool of Xerox copies. The investigator explained the tool and the way of answering the questionnaire. The questionnaire was administered individually to all the student's teachers.

\section{Data Analysis}

Hypothesis 1: The level of the academic self-image of B.Ed., trainees

\section{Table 1: Significant Difference on} the Mean Scores on the total sample

\begin{tabular}{|c|c|c|c|}
\hline & N & Percentile Mean & SD \\
\hline Total & 941 & 96.83 & 11.48 \\
\hline
\end{tabular}

From the above Table 1, it is noted that Mean and SD Scores in the total sample on the level of the academic self-image of B.Ed., trainees were 96.83 and 11.48. Therefore the level of the academic selfimage of B.Ed., trainees is high.

Hypothesis 2: There is no significant difference in the mean scores on the academic self-image of B.Ed., trainees concerning their Gender. 
Table 2: ' $t$ ' value between the mean scores on the Academic Self-Image of B.Ed., Trainees concerning their gender

\begin{tabular}{|c|c|c|c|c|}
\hline Gender & N & $\begin{array}{c}\text { Percentile } \\
\text { Mean }\end{array}$ & $\begin{array}{c}\text { Std. } \\
\text { Deviation }\end{array}$ & 't' value \\
\hline Male & 210 & 96.18 & 11.971 & \multirow{2}{*}{$0.932 * *$} \\
\hline Female & 731 & 97.02 & 11.346 & \\
\hline
\end{tabular}

** - Not Significant at 0.05 level

From the above Table - 2, it is seen that the' value, 0.932 , is not significant at the 0.05 level. It is understood from the result that there is no significant difference in the mean scores on the Academic Self-Image of B.Ed., Trainees concerning their Gender. The mean value of the Male and Female B.Ed., Trainees, are found to be 96.18 and 97.02 , respectively. The obtained't' value 0.932 is lesser than the table value. Therefore the framed null hypothesis is accepted.

Hypothesis 3: There is no significant difference in the mean scores on the academic self-image of B.Ed., trainees concerning their Year of Study.

Table 3: ' $t$ ' value between the mean scores on the Academic Self-Image of B.Ed., Trainees concerning their Year of Study

\begin{tabular}{|c|c|c|c|c|}
\hline $\begin{array}{c}\text { Year of } \\
\text { Study }\end{array}$ & $\mathbf{N}$ & $\begin{array}{c}\text { Percentile } \\
\text { Mean }\end{array}$ & $\begin{array}{c}\text { Std. } \\
\text { Deviation }\end{array}$ & $\begin{array}{c}\text { 't' } \\
\text { value }\end{array}$ \\
\hline First Year & 410 & 95.16 & 11.214 & \multirow{2}{*}{$3.952 *$} \\
\hline Second Year & 531 & 98.12 & 11.540 & \\
\hline
\end{tabular}

* - Significant at 0.05 level

From the above Table - 3 , it is seen that the' value, 3.952 , is significant at 0.05 level. It is understood from the result that there is a significant difference in the mean scores on the Academic Self-Image of B.Ed., Trainees concerning their Year of Study. Second Year B.Ed., Trainees are the significantly higher level of Academic Self-Image than the First Year B.Ed., Trainees. Therefore the framed null hypothesis is rejected.

Hypothesis 4: There is no significant difference in the mean scores on the academic self-image of B.Ed., trainees concerning their Subject.
Table 4: ' $F$ ' value between the mean scores on the Academic Self-Image of B.Ed., Trainees concerning their Subject Subject

\begin{tabular}{|c|c|c|c|c|}
\hline Subject & $\begin{array}{c}\text { Sum of } \\
\text { Squares }\end{array}$ & df & $\begin{array}{c}\text { Mean } \\
\text { Square }\end{array}$ & F \\
\hline $\begin{array}{c}\text { Between } \\
\text { Groups }\end{array}$ & 28.185 & 2 & 14.093 & \multirow{2}{*}{$0.107^{* *}$} \\
\cline { 1 - 3 } $\begin{array}{c}\text { Within } \\
\text { Groups }\end{array}$ & 124021.285 & 938 & 132.219 & \\
\hline Total & 12.4049 .471 & 940 & & \\
\hline
\end{tabular}

** - Not Significant at 0.05 level

It is seen from Table - 4 that the F value 0.107 is not significant at the 0.05 level. It is understood from the result that there is no significant difference in the level of B.Ed., Trainees concerning their Subject at the low level of Academic Self-Image. Therefore the framed null hypothesis is accepted.

Hypothesis 5: There is no significant difference in the mean scores on the academic self-image of B.Ed., trainees concerning their Locality of College.

Table 5: ' $t$ ' value between the mean scores on the Academic Self-Image of B.Ed., Trainees concerning their Locality of College

\begin{tabular}{|c|c|c|c|c|}
\hline $\begin{array}{c}\text { Locality } \\
\text { of College }\end{array}$ & N & $\begin{array}{c}\text { Percentile } \\
\text { Mean }\end{array}$ & $\begin{array}{c}\text { Std. } \\
\text { Deviation }\end{array}$ & $\begin{array}{c}\text { 't' } \\
\text { value }\end{array}$ \\
\hline Rural & 450 & 96.03 & 11.042 & \multirow{2}{*}{$2.063^{*}$} \\
\hline Urban & 491 & 97.57 & 11.845 & \\
\hline
\end{tabular}

From the above Table - 5, it is seen that the' value, 2.063 , is significant at 0.05 level. It is understood from the result that there is a significant difference in the mean scores on the Academic Self-Image of B.Ed., Trainees concerning their Locality of College. Urban B.Ed., Trainees, are the significantly higher level of Academic Self-Image than the Rural B.Ed., Trainees. Therefore the framed null hypothesis is rejected.

Hypothesis 6: There is no significant difference in the mean scores on the academic self-image of B.Ed., trainees concerning their Marital Status. 


\section{Table 6: 't' value between the mean scores on the Academic Self-Image of B.Ed., Trainees concerning their Marital Status}

\begin{tabular}{|c|c|c|c|c|}
\hline $\begin{array}{c}\text { Type of } \\
\text { Family }\end{array}$ & $\mathbf{N}$ & $\begin{array}{c}\text { Percentile } \\
\text { Mean }\end{array}$ & $\begin{array}{c}\text { Std. } \\
\text { Deviation }\end{array}$ & ' $\mathbf{t}$ ' value \\
\hline Married & 328 & 96.03 & 11.086 & \multirow{2}{*}{$1.573^{* *}$} \\
\hline Unmarried & 613 & 97.26 & 11.683 & \\
\hline
\end{tabular}

** - Not Significant at 0.05 level

From the above Table - 6, it is seen that the' value, 1.573, is not significant at the 0.05 level. It is understood from the result that there is no significant difference in the mean scores on the Academic Self-Image of B.Ed., Trainees concerning their Marital Status. The mean value of the married and unmarried B.Ed., trainees, are found to be 96.03 and 97.26 , respectively. The obtained ' $t$ ' value 1.573 is lesser than the table value. Therefore the framed null hypothesis is accepted.

\section{Findings of the Study}

The Salient findings of the study are:

- B. Ed., trainees, have much more academic selfimage.

- The mean value of the Male and Female B.Ed., trainees, are found to be 96.18 and 97.02, respectively, and the $\mathrm{t}-$ value is 0.932 . The calculated t-value 0.932 is lesser than the table value (1.96) at 0.05 levels of significance. Hence it is found that there is no significant difference in the mean scores on the academic self-image of B.Ed., trainees concerning their gender.

- The mean value of the first year and second year B.Ed., trainees are found to be 95.16 and 98.12, respectively, and the t-value is 3.952. The calculated t-value 3.952 is greater than the table value (1.96) at 0.05 levels of significance. Hence it is found that there is a significant difference in the mean scores on the academic self-image of B.Ed., trainees concerning their year of study.

- The mean value of the language subject, art subject, and science subject B.Ed., trainees are found to be $97.12,96.74$, and 96.72 respectively, and the F-value is 0.107 . The calculated $F$ value 0.1047 is lesser than the table value (3.01) at 0.05 levels of significance. Hence it is found that there is no significant difference in the mean scores on the academic self-image of B.Ed., trainees concerning their subject.

- The mean value of the rural and urban area college B.Ed., trainees are found to be 96.03 and 97.57 , respectively, and the $\mathrm{t}$-value is 2.063 . The calculated t-value 2.063 is greater than the table value (1.96) at 0.05 levels of significance. Hence it is found that there is a significant difference in the mean scores on the academic self-image of B.Ed., trainees concerning their locality of college.

- The mean value of the married and unmarried B.Ed., trainees, are found to be 96.03 and 97.26, respectively, and the t-value is 1.573 . The calculated t-value 1.573 is lesser than the table value (1.96) at 0.05 levels of significance. Hence it is found that there is no significant difference in the mean scores on the academic self-image of B.Ed., trainees concerning their marital status.

\section{Discussion of the Study}

- The aim of the present study is to find out the level of the academic self-image of B.Ed., trainees.

- It is found that there is no significant difference between scores on the academic self-image of B.Ed., Trainees concerning gender. This is similar to the findings of Verma and Kumari (2017) conducted a study on a sample of 300 students of Ludhiana (Punjab) to study the academic achievement of children at high school about their self-image. The findings of the study revealed that a significant relationship exists between self-image and academic achievement of high school students. There is a no significant difference found in the self-confidence of male and female high school students.

- It is found that there is a significant difference between scores on the academic self-image of B.Ed., trainees concerning their year of study. The findings indicated a significant difference between the B.Ed., trainee's academic selfimage of First Year and Second Year. The result also showed that Second Year B.Ed., trainees were higher than First-year B.Ed., trainees. 


\section{Recommendations of the Study}

- By practicing many proven cognitive tools such as mnemonics, problem-solving, heuristics, creativity techniques, and decision-making tools. An increase in the self-image level can only result in a better life, health, and standard of living.

- In life, it's not enough to just react to events, and situations, rather student teachers should have a conscious objective and select their actions to get nearer to their objective.

- Also, it's important to think about the consequences of one's actions to minimize the possibilities of errors and regret. Deep thinking would normally help student teachers live better and reach their goals.

- Good reasoning is the key to success. Especially if performed consciously and in the proper order: a) have an objective, b)make general sensing about it, c) determine your decision based on your sensing, d) make alternate plans (along with the main objective), e) select the best response/ plan. f) Start by carrying out your plan, g) observe results, h) store experiences (for future reference).

\section{Suggestion for Further Study}

The present study was confined to the B.Ed., student teachers, whereas, a similar attempt could be made to study of students of all levels of education.

\section{Conclusion}

The present study reveals that there is more number of B.Ed., Trainees have a high academic self-image. The study finally shows that there is no significant difference in the mean scores on the academic self-image of B.Ed., trainees with certain demographic variables. Therefore, the Investigator hopes that the present study would surely help to understand B.Ed., trainees better, so that remedial measures for those lacking in this area may be given an improvement and support to further increase and enhance their Academic Self-Image.

\section{References}

Aggarwal, J.C. Educational Research. Arya Book Depot. Pvt. Ltd, New Delhi, 1986.
Ahmad, Alay and Safaria, Triantoro. "Effects of Self-Efficacy on Student's Academic Achievement." Journal of Educational, Health and Community Psychology, vol. 2, no. 1, 2014, pp. 22-29.

Annie Amala, P. History of Education, Discovery Publishing House, New Delhi, 2004.

Bianchi FT, et al. "Racial Identity and Self-Esteem Among Black Brazilian Men." Cultural Diversity and Ethnic Minority Psychology, vol. 8, no. 2, 2002, pp. 157-169.

Cetin, F.C. and Ulay, H.T. "Effects of Self-Image on Identity Status of Turkish Adolescents." Adolescent Psychiatry, vol. 1, no. 1, 2011, pp. 1-6.

Chitra. D and Karnan. P. "This Study Examined the Self-Acceptance and the Academic Achievement of High School Students in the Vellore District." International Journal of Educational Science and Research, vol. 7, no. 2, 2017, pp. 83-92.

Deepika, B. and D. Geetha. "A Study on Self Concept in Relation to Academic Achievement among B.Ed Trainees." International Journal of Trend in Scientific Research and Development, vol. 2, no. 4, 2018, pp. 2177-2185.

Garrett, H.E. Statistics in Psychology and Education. Paragon International Publishers, New Delhi: 2005.

Harries. Chester. W. Encyclopedia of Educational Research. Mc-Millan Company, New York, 1960.

Hema R Bhadawkar. "A Study of Academic Achievement of B Ed Students in Relation to their Self Esteem." Scholarly Research Journal for Humanity Science \& English Language, vol. 4, 2017, pp. 4447-4462.

Rosnet, E., Scanff L.C. and Sagel, S.M. "How SelfImage and Personality Influence Performance in an Inaccessible Environment." Environment and Behavior, vol. 32, no. 1, 2000, pp. 18-31.

Selvaraj, A., Gnanadevan, R. "Self-Confidence and Stress of Higher Senior Secondary Students of Cuddalore District of Tamil Nadu." Journal of Community Guidance and Research, vol. 31 , no. 1,2014 , pp. 71-77. 
Swann, W.B., Jr. Self-traps: The Elusive Quest for Wells, L. Edward. and Marwell, G. Self-esteem: Its Higher Self-Esteem. W.H. Freeman \& Co. Wells, New York, 1996. Conceptualization and Measurement. Beverly Hills, CA: Sage, 1976.

Wylie, R.C. The Self-Concept (Vol. 2). University of Nebraska, Lincoln, 1979.

\author{
Author Details \\ P. Rajendran, Ph.D. Scholar, Department of Education, Tamil University, Thanjavur, Tamil Nadu, India. \\ Email ID: rajendhp@gmail.com.
}

Dr. R. Anandarasu, Assistant Professor, Department of Education, Tamil University, Thanjavur, Tamil Nadu, India 